University of Michigan Law School

University of Michigan Law School Scholarship Repository

Articles

Faculty Scholarship

1921

\title{
The Permanent International Court of Justice
}

Edwin D. Dickinson

University of Michigan Law School

Available at: https://repository.law.umich.edu/articles/1109

Follow this and additional works at: https://repository.law.umich.edu/articles

Part of the Courts Commons, International Law Commons, and the Organizations Law Commons

\section{Recommended Citation}

Dickinson, Edwin D. "The Permanent International Court of Justice." Mich. L. Rev. 19 (1921): 413-5.

This Response or Comment is brought to you for free and open access by the Faculty Scholarship at University of Michigan Law School Scholarship Repository. It has been accepted for inclusion in Articles by an authorized administrator of University of Michigan Law School Scholarship Repository. For more information, please contact mlaw.repository@umich.edu. 


\section{Michigan LaW Review}

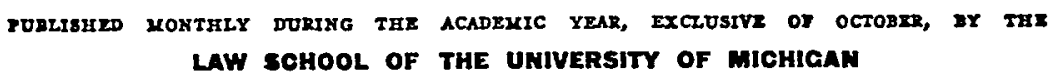

RALPH W. Aigler, EDTTOR-IN-ChIEF ASSOCIATE EDITORS

HENRY M. BATES

E. C. GodDARD
Eidson R. SUNDERLAND JOSEPH H. DRAKE

JohN B. WAITE

STUDENTS, APPOINTED BY THE FACULTY

Herman A. August, of Michigan Olive N. Barton, of Michigan

A. GEORGE Bouchard, of Wisconsin ALAN W. Boyd, of Indiana

D. Hale Brake, of Michigan

Carr G. Brandt, of Michigan

Frederick D. Chrrolx, of Michigan

George D. Ciapperton, of Michigan

RALPH E. GAULT, of Michigan

Paul W. Gormon, of Illinois
Jahies I. McCimtock, of Colorado Lewis H. Mattere, of Ohio Wirina C. O'KeEFE, of Michigan Lovis A. PArker, of lowa Frank C. Parterson, of Michigan Hakozd M. Shapero, of Michigan HArold R. Smitr, of Michigan WINTER N. SNow, of Maine JEAN Paul Thoman, of Michigan Glen N A. Trevor, of Illinois

Charles E. Turner, of Illinois

\section{NOTE AND COMMENT}

The Permanent International, Court of Justice.-For the first time in history leading powers both great and small have been able to agree upon a plan for an international court of justice. The plan was formulated last summer by an advisory committee of jurists sitting at The Hague. Since then it has been submitted to the Council and the Assembly of the League of Nations and has been approved. It will come into operation as soon as the project has been ratified by a majority of the nations belonging to the League. $^{1}$

The Permanent Court of International Justice, as it is called, will be more than a mere panel from which arbitration tribunals may be constituted from time to time, and it will be much less than a supreme court of the world. It will be more than a mere panel of arbitrators because it is to be a permanent institution established to develop and apply rules of law. It will

2 The text of the project with a commentary by $J$. B. Scott may be found in Pamphlet No. 35 recently issued by the Division of International Law of the Carnegie Endowment for International Peace. Other data taken from current periodicals and press reports. 
be less than a supreme court because, as approved by the League, it is to have no obligatory jurisdiction. The draft-scheme provides for organization, competence, and procedure. The procedure is to be very simple and in general much like the system already developed in arbitrations at The Hague. There will be written proceedings, consisting of the submission of cases, counter-cases, and, if necessary, replies, and also oral proceedings consisting of the hearing of witnesses, experts, agents, and counsel. Details of procedure are wisely left to be settled by the Court itself. Decisions are to be made by majority vote; the judgment must state the reasons upon which it is based; dissenting judges may have the fact of their dissent, but not their reasons, recorded in the judgment.

The matter of competence is more important. It was readily agreed that the Court should decide cases submitted by the parties under general or special convention. It was also agreed that in the absence of general or special convention, jurisdiction should be limited to disputes of a justiciable nature between states which the states themselves are unable to settle by diplomacy. Should jurisdiction within these limits be obligatory or voluntary? The advisory committee recommended obligatory jurisdiction in all controversies of a legal nature involving (a) the interpretation of a treaty, (b) any question of international law, (c) the existence of any fact which, if established, would constitute a breach of an international obligation, (d) the nature or extent of reparation to be made for the breach of an international obligation, and (e) the interpretation of a sentence passed by the Court. The recommendation was well received by the smaller nations. It was opposed by the great powers, however, and the project was finally approved with the obligatory feature eliminated. The five categories provide an admirable enumeration of the kinds of controversy which the Court is specially qualified to decide, but the submission of such controversies remains optional with the parties. The Court is to apply, in the order named, treaties, custom, general principles of law common to all civilized peoples, and the judicial decisions and juristic writings of the various nations. It is also required to give advisory opinions on questions referred to it by the League Council or Assembly.

The real difficulty, and one which threatened to prove insuperable, was the problem of the Court's composition. There are great powers and small powers, strong powers and weak powers, powers which are advanced in the civilization which is characteristic of the twentieth century and others which are backward. The great powers will never submit to any tribunal dominated by the small, weak, and backward. The lesser powers know all too well the dangers that inhere in the predominance of the great. How may a tribunal be constituted among the fifty or more nations of the earth which will satisfy the strong, safeguard the weak, be fairly representative, and yet be small enough to function as a court? This problem prevented agreement upon a plan before the world war. It threatened to disrupt the advisory committee in 1920 . The committee's membership was divided equally between nationals of great and small powers. Members from the more powerful 
states contended for permanent representation on the proposed court for the great powers. Members from the smaller states insisted upon equality. Elihu Root, in what may some day be regarded as the crowning achievement of his career, piloted the committee to a satisfactory compromise. Taking advantage of the existing League organization, and ably seconded by Lord Phillimore, Mr. Root proposed a small court elected by the concurrent vote of the League Council, in which the great powers are dominant, and the League Assembly, in which all powers are represented equally. This proposal was accepted and became the basis for the plan eventually adopted.

The Court will consist at the outset of fifteen members, eleven judges and four deputy judges. The members are to be elected from a list of candidates nominated by the national groups which constitute the panel of the so-called Permanent Court of Arbitration. Each national group may nominate two candidates. If the Council and Assembly fail to agree on fifteen members after three sittings, a small conference committee, called a Committee of Mediation, will attempt to agree upon candidates to be recommended for the unfilled positions. If this does not result in an election, the members already elected to the Court may fill the vacancies by selection from among the candidates who have received votes in either the Council or the Assembly. Election is for nine years and members are eligible for reelection. While national political office is declared incompatible with a position on the Court, it seems to have been the opinion of the advisory committee that this should not disqualify members of national courts or legislative bodies. If a state which is party to a controversy submitted to the Court has no national on the Court, it is assured the right to name a judge who shall sit during the trial and disposition of that particular controversy. The Court will sit at The Hague.

The plan naturally makes a few concessions to the civil law countries for which the justification is none too obvious to lawyers trained in a different system. There are several features which seem open to criticism, notably the provision which makes French the sole official language and the method of nominating candidates. These, however, are after all secondary matters which may be amended as experience suggests. The project on the whole is a remarkable one and one that does credit to the sagacity and statesmanship of the jurists who labored on the advisory committee. This project alone, it is believed, would more than justify the retention of the existing organization of the League.

E. D. D. 